\title{
INSECTICIDAL ACTIVITY OF CITRONELLA GRASS ESSENTIAL OIL ON Frankliniella schultzei AND Myzus persicae
}

\author{
Atividade inseticida do óleo essencial de capim-citronela \\ sobre Frankliniella schultzei e Myzus persicae \\ Patrícia Fontes Pinheiro', Vagner Tebaldi de Queiroz ${ }^{1}$, Vando Miossi Rondelli², \\ Adilson Vidal Costa ${ }^{3}$, Tiago de Paula Marcelino ${ }^{4}$, Dirceu Pratissoli ${ }^{5}$
}

\begin{abstract}
The thrips, Frankliniella schultzei, and green peach aphid, Myzus persicae, cause direct damage to plants of economic importance and transmit phytoviruses, causing large economic losses. Chemical constituents of essential oils present a wide range of biological activities. The aim of this work was to evaluate insecticidal activity of essential oil from citronella grass, Cymbopogon winterianus, on $F$. schultzei and $M$. persicae. This essential oil was obtained by steam distillation and components were identified by GC/FID and GC/MS. A Potter spray tower was used to spray insects with the essential oil. The major constituents are geraniol (28.62\%), citronellal $(23.62 \%)$ and citronellol (17.10\%). Essential oil of $C$. winterianus at $1 \%\left(\mathrm{w} \mathrm{v}^{-1}\right)$ causes mortality in $F$. schultzei and $M$. persicae at $34.3 \%$ and $96.9 \%$, respectively. The $\mathrm{LC}_{50}$ value for $M$. persicae was $0.36 \%$ and $\mathrm{LC}_{90} 0.66 \%$. Thus, citronella grass essential oil at $1 \%\left(\mathrm{w} \mathrm{v}^{-1}\right)$ is more toxic to M. persicae than $F$. schultzei. This essential oil shows promise for developing pesticides to manage M. persicae.
\end{abstract}

Index terms: Cymbopogon winterianus, thrips, green peach aphid, volatile components, natural insecticide.

\section{RESUMO}

O tripes, Frankliniella schultzei, e o pulgão-verde, Myzus persicae, além de causarem danos diretos a plantas de importância econômica, também são importantes transmissores de fitoviroses, acarretando grandes perdas econômicas. Os constituintes químicos dos óleos essenciais têm sido cada vez mais estudados, pois apresentam uma ampla gama de atividades biológicas. Neste trabalho, objetivou-se avaliar a atividade inseticida do óleo essencial de capim-citronela, Cymbopogon winterianus, sobre $F$. schultzei e $M$. persicae. O óleo essencial foi obtido por hidrodestilação e a identificação dos seus componentes foi realizada por CG/DIC e CG/EM. Uma torre de Potter foi utilizada para pulverizar os insetos com óleo essencial. Os componentes majoritários encontrados são geraniol $(28,62 \%)$, citronelal $(23,62 \%)$ e citronelol $(17,10 \%)$. O óleo essencial de $C$. winterianus a $1 \%\left(\mathrm{~m} \mathrm{v}^{-1}\right)$ causa mortalidade de $F$. schultzei e $M$. persicae em 34,3\% e 96,9\%, respectivamente. $\mathrm{O}$ valor estimado de $\mathrm{CL}_{50}$ para $M$. persicae foi $0,36 \%$ e $\mathrm{CL}_{90}$ de $0,66 \%$. Assim, o óleo essencial de capim-citronela a $1 \%\left(\mathrm{~m} \mathrm{v}^{-1}\right)$ é mais tóxico para $M$. persicae do que para $F$. schultzei. Este óleo essencial mostra-se promissor para o desenvolvimento de inseticidas para o manejo de M. persicae.

Termos para indexação: Cymbopogon winterianus, tripes, pulgão-verde, componentes voláteis, inseticida natural.

(Received in november 11, 2012 and approved in february 1, 2013)

\section{INTRODUCTION}

The thrips, Frankliniella schultzei (Trybom) (Thysanoptera: Thripidae), presents piercing/sucking mouthparts, causing necrosis and deformation in the plant tissues it feeds on. Due to injuries caused by feeding and transmitting phytoviruses, this insect causes great economic losses to crops such as tomatoes, cotton, soybeans and grapes (GALLO et al., 2002; MOREIRA; ARAGÃO, 2009; FERNANDES et al., 2011; MOREIRA et al., 2012). F. schultzei transmits Tospovirus, Groundnut ring spot virus (GRSV) and Tomato spotted wilt virus (TSWV) to tomatos and is a more efficient GRSV vector than F. occidentalis (Pergande). F. schultze $i$ was the second most frequently identified species (35.6\%) in tomato flowers (BORBÓN et al., 2006). Between 1996 and 2006, tospoviruses caused annual average losses of $\$ 9$ million to tomato and pepper crops in the state of Georgia (USA) (RILEY et al., 2011).

1Universidade Federal do Espírito Santo/UFES - Departamento de Química e Física - Alegre - ES - Brasil

2Universidade Federal Rural de Pernambuco/UFRPE - Departamento de Agronomia/Entomologia - Recife - PE - Brasil

${ }^{3}$ Universidade Federal do Espírito Santo/UFES - Centro de Ciências Agrárias - Departamento de Química e Física - Alto Universitário - s/no 29500-000 - Alegre - ES - Brasil - avcosta@hotmail.com

${ }^{4}$ Universidade Federal do Espírito Santo/UFES - Departamento de Farmácia e Nutrição - Alegre - ES - Brasi

5 Universidade Federal do Espírito Santo/UFES - Departamento de Produção Vegetal - Alegre - ES - Brasil

Ciênc. agrotec., Lavras, v. 37, n. 2, p. 138-144, mar./abr., 2013 
Another pest of economic importance is the green peach aphid, Myzus persicae (Sulzer) (Hemiptera: Aphididae). This aphid sucks sap from leaves and young shoots, causing intense leaf curling in regions with high populations. However, the main injury this pest causes is transmitting viruses to plants (GALLO et al., 2002). $M$. persicae transmits Potato virus Y (PVY), Tomato yellow top virus (ToYTV) and Tomato bottom yellow leaf virus (TBYLV) to tomato crops. In Brazil, PVY causes between 20 and $70 \%$ of tomato crop losses and ToYTV can reduce the production of flowers and fruits by about $85 \%$ (KUROZAWA; PAVAN, 2005). On eggplant leaves at a temperature of $25^{\circ} \mathrm{C}$, this insect completes its development in just 5.9 days (CHAGAS FILHO et al., 2005).

Because $F$. schultzei and $M$. persicae have short life cycles (PINENT; CARVALHO, 1998; CHAGAS FILHO et al., 2005), these insects have great potential to develop chemical resistance to insecticides. As a result of the emergence of resistant populations (FURIATTI; LAZZARI, 2003; LUOGEN et al., 2005; DOĐRAMACI; TINGEY, 2008), demand has increased for agricultural pest control methods that offer safety to humans, selectivity to natural enemies, biodegradability, economic viability and low environmental impact (VIEGAS, 2003).

In this respect, the use of essential oils for controlling insects has obtained satisfactory results (SOARES et al., 2008; LIMA et al., 2009; LIMA et al., 2011). Essential oil from Cymbopogon winterianus Jowitt, popularly known as citronella grass, has an acaricide (OLIVO et al., 2008) and repellent effect (LABINAS; CROCOMO, 2002). Acaricidal properties of this oil are attributed to the presence of volatile substances such as citronellal, geraniol and citronellol (MARTINS, 2006). Therefore, the aim of this study was to evaluate the effect of $C$. winterianus essential oil on controlling $F$. schultzei and $M$. persicae.

\section{MATERIAL AND METHODS}

\section{Plant material acquisition}

Fresh leaves of $C$. winterianus were collected during morning (March 2012) in an experimental greenhouse of the Center of Agricultural Sciences of the Federal University of Espírito Santo (CCA/UFES), in the municipality of Alegre, Espírito Santo State, Brazil (20 44' 49" S, 41 ${ }^{\circ} 27^{\prime} 58^{\prime \prime} \mathrm{W}$ ) and an altitude of $250 \mathrm{~m}$. C. winterianus was identified by DSc. Tatiana Tavares Carrijo (Department of Biology/CCA/UFES) and exsiccation (n. 21537) has been deposited at the herbarium of the Federal University of Espírito Santo-(VIES)-Alegre Campus.

\section{Extraction of the essential oil}

Essential oil of $C$. winterianus was obtained by steam distillation at the Center for Scientific and Technological Development in Phytosanitary Management of Pests and Diseases (NUDEMAFI) at CCA/UFES according to Wasiky and Akisue (1969).

A sample of fresh plant material $(300 \mathrm{~g})$ was transferred to a distillation flask containing distilled water (2 L). The flask was attached to a Clevenger apparatus, which was attached to the condenser. Steam distillation continued for $2 \mathrm{~h}$ after initial boiling. The organic phase was collected by liquid-liquid extraction of the hydrolate $(100 \mathrm{~mL})$ with pentane $(30 \mathrm{~mL})$. An excess amount of anhydrous sodium sulfate was added to remove water from the sample, which was then filtered. The filtrate was transferred to the rotary evaporator apparatus (MARCONI, MA-120 series) to acquire the essential oil (CASTRO et al., 2004). The yield was calculated using the amount of essential oil $(\mathrm{g})$ obtained relative to the fresh weight $(\mathrm{g})$ of the leaves.

\section{Essential oil chemical characterization}

Volatile components of $C$. winterianus were identified by gas chromatography coupled with mass spectrometry (GC-MS) with a mass selective detector, model QP-PLUS-2010(SHIMADZU). The chromatographic column used was a fused silica capillary column with stationary phase Rtx-5MS, $30 \mathrm{~m}$ long and $0.25 \mathrm{~mm}$ in internal diameter, using helium as the carrier gas. Temperature of the injector and detector were $220^{\circ} \mathrm{C}$ and $300^{\circ} \mathrm{C}$, respectively. The initial column temperature was $60^{\circ} \mathrm{C}$, programmed for an increase of $3^{\circ} \mathrm{C}$ per min until reaching a maximum temperature of $240^{\circ} \mathrm{C}$ (CASTRO et al., 2004). Each essential oil component was identified by comparing their Kóvats retention index relative to a standard alkane series $\left(\mathrm{C}_{9}-\mathrm{C}_{26}\right)$ and comparing its mass spectrum with reference data from the equipment database (NIST/EPA/ NIH08 Mass Espectral Library) and the literature (ADAMS, 2007). Kováts retention indexes of each compound were calculated using equation 01 (LUBECK; SUTTON, 1983):

$$
K I=100 Z-100 \frac{\log t_{R}^{\prime} X-\log t_{R}^{\prime} Z}{\log t^{\prime}{ }_{R}(Z+1)-\log t^{\prime}{ }_{R} Z}
$$

Where: $\mathrm{Z}$ is the carbon number of the alkane eluting just before the analyte, $t^{\prime}{ }_{R} X$ is the retention time of the analyte, $\mathrm{t}_{\mathrm{R}} \mathrm{Z}$ is the retention time of the alkane eluting just before the analyte, $\mathrm{t}_{\mathrm{R}}(\mathrm{Z}+1)$ is the retention time of the alkane eluting just after the analyte. 
Quantification of chemical constituents in the essential oil was performed using a SHIMADZU GC-2010 Plus gas chromatograph, equipped with a flame ionization detector (GC-FID). The carrier gas used was nitrogen with the Rtx-5MS capillary column, measuring $30 \mathrm{~m}$ long and $0.25 \mathrm{~mm}$ in internal diameter. Temperatures of the injector and detector were fixed at 240 and $250^{\circ} \mathrm{C}$, respectively. The temperature program of the furnace was the same as that used in the GC-MS analyses. A $10 \mathrm{mg}$ sample was diluted in dichloromethane $(1 \mathrm{~mL})$, followed by a $1 \mu \mathrm{L}$ injection (CASTRO et al., 2004).

\section{Acquisition and rearing of insects}

\section{F. schultzei}

F. schultze $i$ was collected from jack-bean flowers, Canavalia ensiformis L., located at CCA/UFES in the municipality of Alegre. Insects were maintained in an incubator at $25 \pm 1^{\circ} \mathrm{C}$, relative humidity of $70 \pm 10 \%$ and photoperiod of $12 \mathrm{~h}$ in acrylic cages with a square base measuring $121.0 \mathrm{~cm}^{2}$ and $3.2 \mathrm{~cm}$ in height. Moistened filter paper was placed in the bottom of the cage to maintain humidity. Every two days one cotyledon leaf measuring roughly $18 \mathrm{~cm}$ in height of the natural host, jack bean, was provided to feed the nymphs. These leaves were collected and approximately $3 \mathrm{~cm}$ of the petiole was inserted in a cotton swab followed by anesthetic vials of $0.7 \times 5.0 \mathrm{~cm}$ (diameter and height) containing distilled water to maintain turgidity. Plants were grown in 72-cell styrofoam trays containing a mixture of soil and cattle manure in a $6: 1$ proportion.

The cages were sealed with plastic wrap containing small holes. After copulation ( $48 \mathrm{~h}$ after the emergence of adults), the insects were sexed and 60 females were placed in each cage, since oviposition is reduced when females are in the presence of males. Cotyledon leaves containing castor bean pollen, Ricinus communis L., at the base for improved reproduction performance were offered everyday for feeding and oviposition of the females. Eggs were collected daily and transferred to new cages (RONDELLI et al., 2012).

\section{M. persicae}

M. persicae was obtained from kale plants, Brassica oleracea var. acephala DC., in the municipality of Alegre, Espírito Santo State, Brazil. They were reared in an incubator at $25 \pm 1^{\circ} \mathrm{C}$, relative humidity of $70 \pm 10 \%$ and photoperiod of $12 \mathrm{~h}$ on $8.0 \mathrm{~cm}$ diameter leaf discs of organic kale, in Petri dishes measuring $9.0 \times 1.3 \mathrm{~cm}$ (diameter and height) and lined with filter paper. Every two days the plates were cleaned $70 \%$ alcohol and the filter paper and leaf discs were exchanged, while the insects were transferred with the aid of a bristle brush.

\section{Insecticide activity test}

Test solution was prepared by dissolving $1.5 \mathrm{~g}$ of citronella grass essential oil in a mixture of acetone $(3 \mathrm{~mL})$ and Tween $80^{\circledR}(15 \mu \mathrm{L})$. The volume was completed to 150 $\mathrm{mL}$ with distilled water for a mixture with essential oil at $1 \%$ $\left(\mathrm{W} \mathrm{V}^{-1}\right)$. A $150 \mathrm{~mL}$ solution with this same composition, but lacking essential oil, was used as a control.

F. schultzei nymphs between 48 and $72 \mathrm{~h}$ of age in the first or second instar were used for bioassay purpose (PINENT; CARVALHO, 1998). Ten F. schultzei nymphs were transfered to the abaxial face of jack-bean cotyledonary leaves (repetition) with the aid of a fine-bristle brush and funnel with a cut tip, since they are very agile. The test solutions containing essential oil were sprayed on both sides of the leaf. A cotton swab was placed on the petiole of the jack-bean leaves and placed in an anesthetic vial containing distilled water to maintain leaf turgidity. The dishes were sealed with plastic wrap containing six pin holes to allow gas and moisture exchange.

The bioassay was carried out with $M$. persicae nymphs between 24 and $48 \mathrm{~h}$ of age in the first or second instar (CHAGAS FILHO et al., 2005). Ten M. persicae insects were placed on the abaxial face of organic kale leaf discs measuring $4.5 \mathrm{~cm}$ in diameter (repetition). Essential oil was sprayed on both sides of the leaf and the Petri dish was closed with its own lid.

The leaves containing the insects were placed in Petri dishes measuring $9.0 \times 1.3 \mathrm{~cm}$ coated with filter paper and sprayed using a Potter tower with a pressure of $15 \mathrm{lb}$ $i^{-2}$ and $6 \mathrm{~mL}$ of the solution for each leaf side $(12 \mathrm{~mL} /$ repetition), spreading an average volume of $1.62 \mathrm{mg} \mathrm{cm}^{-2}$ (RONDELLIet al., 2011). Plates were maintained in a climatic chamber at $25 \pm 1^{\circ} \mathrm{C}$, relative humidity of $70 \pm 10 \%$ and photoperiod of $12 \mathrm{~h}$, at the NUDEMAFI. Leaves were exchanged on the second day and as needed. Mortality was assessed until the fifith day.

A completely randomized design with 10 replicates containing 10 insects each was used. The corrected mortality was calculated in relation to the control with the Abbott (1925) formula. Data were subjected to analysis of variance and means were compared by the Fisher's test at $5 \%$ probability.

\section{Estimate of lethal concentration (LC)}

The lethal concentration was estimated only for $M$. persicae. Nine concentrations of the citronella grass 
essential oil were used $(0,0.020,0.050,0.100,0.163,0.257$, $0.391,0.595,0.906$ and $\left.1.240 \%\left(\mathrm{w} \mathrm{v}^{-1}\right)\right)$, spaced on a logarithmic scale. Lower and upper limits were determined by preliminary tests. The control consisted of $2 \%\left(\mathrm{v} \mathrm{v}^{-1}\right)$ acetone and $0.01 \%\left(\mathrm{w} \mathrm{V}^{-1}\right)$ Tween 80 diluted in distilled water. This stage of the bioassay was performed according to the procedures adopted in the insecticidal activity test. Mortality was assessed until the fifth day. A completely randomized design with five replicates each containing 10 insects was used. The lethal concentration was estimated according to the Probit analysis using the Polo-PC program (LEORASOFTWARE, 1987).

\section{RESULTS AND DISCUSSION}

\section{Chemical characterization of the essential oil}

The yield of the essential oil was $2.02 \%\left(\mathrm{w} \mathrm{w}^{-1}\right)$. Essential oil obtained from fresh leaves of $C$. winterianus showed yield of $0.5 \%$ (GONÇALVES et al. 2010). Chemical composition for $C$. winterianus essential oil is described (Table 1). The main components found in the citronella grass essential oil in the present study were geraniol (28.62\%), citronellal (23.62\%) and citronellol (17.10\%); these compounds are classified as monoterpenes. The presence of citronellal and citronellol was also detected by Labinas and Crocomo (2002) and by Quintas-Júnior et al. (2008), with the latter also reporting the presence of geraniol (40.06\%) as the main component of citronella grass essential oil, followed by citronellal (27.44\%) and citronellol $(10.45 \%)$. The predominance of those same components in the essential oil of $C$. winterianus was also determined by Leite et al. (2011), who found citronellal (36.19\%), geraniol (32.82\%) and citronellol (11.37\%).

In addition to the identification of citronellol and geraniol, elemol, a sesquiterpene, was also identified in $C$. winterianus by Akhila (1986) as one of the major components in this essential oil. This component was also identified in this study, corresponding to $5.27 \%$ of the oil (Table 1).

The quantity and chemical composition of essential oils produced by plants can vary within a species as a function of environmental conditions, interactions between plant/plant, plant/microorganisms, plants/insects and factors such as age, development and abiotic factors including light, temperature, rainfall, nutrition, season and collection time (MORAIS, 2009).

Monoterpenes present in the oil, such as limonene, citronellal and geraniol activate plant chemical defenses against insect pests (IBRAHIM et al., 2001; HUMMELBRUNNER; ISMAN, 2001; GALLARDO et al.,
2012). Furthermore, geraniol has anti-septic activity, inhibiting the growth of fungi and bacteria (CHEN; VIJOEN, 2010).

Table 1 - Chemical components of the essential oil of citronella grass, Cymbopogon winterianus, presented as calculated and tabulated Kovats indices and percentage of the compound.

\begin{tabular}{lccc}
\hline Compound & $\mathrm{KI} \mathrm{cal}^{\mathrm{a}}$ & $\mathrm{KI} \mathrm{tab}^{\mathrm{b}}$ & $\%$ Area \\
\hline Limonene & 1036 & 1031 & 0.95 \\
Linalool & 1104 & 1098 & 0.67 \\
Isopulegol<neo> & 1153 & 1145 & 1.53 \\
Citronellal & 1161 & 1153 & 23.62 \\
Citronellol & 1236 & 1228 & 17.10 \\
Neral & 1249 & 1240 & 0.49 \\
Geraniol & 1263 & 1255 & 28.62 \\
Geranial & 1278 & 1270 & 0.63 \\
Terpinen-4-ol acetate & 1341 & 1340 & 5.72 \\
citronella acetate & 1360 & 1354 & 1.09 \\
NI & 1362 & - & 3.33 \\
Eugenol & 1365 & 1356 & 0.15 \\
Geranyl Acetate & 1383 & 1389 & 1.69 \\
Beta-Elemene & 1397 & 1391 & 0.53 \\
Germacrene-D & 1485 & 1480 & 0.83 \\
Delta-Cadinene & 1531 & 1524 & 1.25 \\
Elemol & 1557 & 1549 & 5.27 \\
NI & 1583 & - & 1.45 \\
Beta-Eudesmol & 1641 & 1649 & 0.52 \\
Torreol & 1651 & 1645 & 1.44 \\
alpha -Cadinol & 1663 & 1653 & 2.96 \\
\hline Calculed Kovats & & & \\
\hline
\end{tabular}

${ }^{\mathrm{a} C a l c u l a t e d ~ K o v a t s ~ I n d e x . ~}{ }^{\mathrm{b}}$ Tabulated Kovats Index (ADAMS, 2007). ' Unidentified.

\section{Insecticide activity test}

The citronella grass essential oil at a concentration of $1 \%\left(\mathrm{w} \mathrm{v}^{-1}\right)$ was toxic to both pests evaluated, however a higher corrected mortality $(96.9 \pm 1.57 \%)$ (mean \pm standard error) was observed for $M$. persicae than $F$. schultzei $(34.3$ $\pm 3.77 \%)\left(\mathrm{F}_{1,18}=235.96 ; \mathrm{P}<0.0001\right)$. In the control with $F$. schultzei, the observed mortality was $5.7 \pm 3.67 \%$ and in the control with $M$. persicae, the observed mortality rate was $8.0 \pm 2.92 \%$.

The insecticidal activity of $C$. winterianus essential oil $\left(500 \mu \mathrm{g} \mathrm{L}^{-1}\right)$ was evaluated against Aedes aegypti (L.) (Diptera: Culicidae) larvaes and presented $100 \%$ mortality 
after $48 \mathrm{~h}$ (MENDONÇA et al., 2005). Furthermore, the acaricide action of the principal components of the essential oil of $C$. winterianus was evaluated separately against engorged adult females and larvae from the tick Boophilus microplus (Canestrini, 1887), which showed that citronellal and geraniol have significantly stronger action than citronellol, indicating a shared action between them (MARTINS, 2006).

In addition to mortality, essential oils can cause deformations in different stages of insect development, repellence and deterrence. When essential oils interact with the integument of insects, it may affect digestive and neurological enzymes (ISMAN, 2006).

\section{Estimate of the lethal concentration (LC)}

The $\mathrm{LC}_{50}$ of the citronella grass essential oil on $M$. persicae was $0.36 \%$ and the confidence interval at $95 \%$ probability was 0.30 to 0.41 . The $\mathrm{LC}_{90}$ was $0.66 \%$ and the confidence interval was 0.57 to 0.81 . The slope of the concentration-response curve of the citronella grass essential oil on $M$. persicae was high (4.79). High values of the slope of the concentration-response curve indicate that a small variation in concentration of the essential oil promotes large variations in mortality. The number of insects used in the test was 360, with five degrees of freedom and a chi-squared value of 4.21 .

Citronella grass essential oil applied to Spodoptera frugiperda (Smith) (Lepidoptera: Noctuidae) at $0.5 \%$ sprayed on the surface of a Petri dish caused nearly $100 \%$ larval mortality (LABINAS; CROCOMO, 2002). When cardboard disks were immersed for five minutes in $C$. winterianus essential oil at a concentration of $0.2 \%\left(\mathrm{v} \mathrm{v}^{-1}\right)$ and offered to the termite species Nasutitermes corniger Motschulsky (Isoptera: Termitidae), 100\% insect mortality was observed after $24 \mathrm{~h}$ (SOARES et al., 2008).

Values of the $\mathrm{LC}_{50}$ and $\mathrm{LC}_{90}$ calculated for citronella grass essential oil on larvae of A. aegypti were 98 and 172 $\mu \mathrm{g} \mathrm{L}{ }^{-1}$, respectively (MENDONÇA et al., 2005). In another study at a concentration of $50 \mu \mathrm{g} \mathrm{L}^{-1}$, this oil caused $60 \%$ mortality in A. aegypti larvae after $24 \mathrm{~h}$ (AMER; MEHLHORN, 2006). Essential oils also have a repellent effect on various pests (LABINAS; CROCOMO, 2002; ISMAN, 2006), which is an important feature of virus vectors such as those studied in this work.

Verifying insecticidal activity in essential oils and determining their active components may serve as a basis for creating new commercial insecticides, seeking to develop and expand alternative methods to increase production in agroecosystems and reduce synthetic insecticide use.

\section{CONCLUSIONS}

Results obtained show that the essential oil of citronella grass at $1 \%\left(\mathrm{w} \mathrm{v} \mathrm{v}^{-1}\right)$ caused significant mortality to $M$. persicae $(96.9 \pm 1.57 \%)$, and was less toxic to $F$. schultzei $(34.3 \pm 3.77 \%)$. The $\mathrm{LC}_{50}$ value for $M$. persicae was $0.36 \%$ and $\mathrm{LC}_{90} 0.66 \%$. Therefore, this essential oil is a promising option for developing pesticides to manage $M$. persicae.

\section{ACKNOWLEDGEMENTS}

To the Coordenação de Aperfeiçoamento de Pessoal de Nível Superior (CAPES) for providing a PhD scholarship to Vando Rondelli and the Conselho Nacional de Desenvolvimento Científico e Tecnológico $(\mathrm{CNPq})$ for granting a research productivity grant to Dirceu Pratissoli.

\section{REFERENCES}

ABBOTT, W.S. A method of computing the effectiveness of an insecticide. Journal of Economic

Entomology, College Park, v.18, n.1, p.265-267, jan, 1925.

ADAMS, R.P. Identification of essential oil components by gas cromatography/mass spectroscopy. Illinois:

Allured, 2007, 804p.

AKHILA, A. Biosynthesis of monoterpenes in Cymbopogon winterianus. Phytochemistry, New York, v.25, n.2, p.421-424, jan, 1986.

AMER, A.; MEHLHORN, H. Larvicidal effects of various essential oils against Aedes, Anopheles, and Culex larvae (Diptera, Culicidae). Parasitology Research, Berlin, v.99, n.4, p.466-472, apr, 2006.

BORBÓN, C.M. de; GRACIA, O.; PÍCCOLO, R. Relationships between tospovirus incidence and thrips populations on tomato in Mendoza, Argentina. Journal of Phytopathology, Berlin, v.154, n.2, p.93-99, feb, 2006.

CASTRO, H.G. et al. Teor e composição do óleo essencial de cinco acessos de mentrasto. Química Nova, São Paulo, v.27, n.1, p.55-57, jan./feb, 2004.

CHAGAS FILHO, N.R. et al. Desenvolvimento ninfal de Myzus persicae (Sulzer, 1776) (Hemiptera: Aphididae) sobre berinjela em diferentes temperaturas. Bragantia, Campinas, v.64, n.2, p.257-262, apr./jun, 2005. 
CHEN, W.; VIJOEN, A.M. Geraniol - A review of a commercially important fragrance material. South African Journal of Botany, Scottsville, v.76, p.643-651, oct, 2010.

DOĐRAMACI, M.; TINGEY, W.M. Comparison of insecticide resistance in a North American field population and a laboratory colony of potato tuberworm (Lepidoptera: Gelechiidae). Journal of Pest Science, Berlin, v.81, n.1, p.17-22, mar, 2008.

FERNANDES, M.G. et al. Sequential sampling of Aphis gossypii Glover (Hemiptera: Aphididae) and Frankliniella schultzei Trybom (Thysanoptera: Thripidae) on cotton crop. Neotropical Entomology, Londrina, v.40, n.2, p.258-263, mar./apr, 2011.

FURIATTI, R.S.; LAZZARI, S.M.N. Relação entre a atividade de esterases e a resistência de Myzus persicae (Sulz.) (Sternorrhyncha: Aphididae) a pirimicarbe. Neotropical Entomology, Londrina, v.32, n.4, p.693-697, oct./dec, 2003.

GALLARDO, A. Insecticidal activity of individual and mixed monoterpenoids of geranium essential oil against Pediculus humanus capitis (Phthiraptera: Pediculidae). Journal of Medical Entomology, Lanham, v.49, n.2, p.332-335, mar, 2012.

GALLO, D. et al. Entomologia agrícola. Fealq, Piracicaba, 2002, 920p.

GONÇALVES, T.B. et al. Chemical composition and antibacterial evaluation of the essential oil from Cymbopogon winterianus Jowitt (Gramineae). Journal of Essential Oil-Bearing Plants, Dehradun, v.13, n.4, p.426-431, jul, 2010.

HUMMELBRUNNER, L.A., ISMAN, M.B. Acute, sublethal, antifeedant, and synergistic effects of monoterpenoid essential oil compounds on the tobacco cutworm, Spodoptera litura (Lep., Noctuidae). Journal of Agricultural and Food Chemistry, Washington, v.49, n.2, p.715-720, feb, 2001.

IBRAHIM, M.A. et al. Insecticidal, repellent, antimicrobial activity and phytotoxicity of essencial oils: with special reference to limonene and its suitability for control of insect pest. Agricultural and Food Science in Finland, Finland, v.10, p.243-259, apr, 2001.
ISMAN, M.B. Botanical insecticides, deterrents, and repellents in modern agriculture and an increasingly regulated world. Annual Review of Entomology, Stanford, v.51, n.1, p.45-66, jan, 2006.

KUROZAWA, C; PAVAN, M.A. Doenças do tomateiro. In: KIMATI, H. et al. Manual de fitopatologia: doenças das plantas cultivadas. São Paulo: Agronômica Ceres, p.607-626, 2005.

LABINAS, M.A.; CROCOMO, W.B. Effect of java grass (Cymbopogon winterianus) essential oil on fall armyworm Spodoptera frugiperda (J. E. Smith, 1979) (Lepidoptera, Noctuidae). Acta Scientiarum, Maringá, v.24, n.5, p.1401-1405, sept./oct, 2002.

LEITE, B.L.S. et al. Volatile constituents and behavioral change induced by Cymbopogon winterianus leaf essential oil in rodents. African Journal of Biotechnology, Nairobi, v.10, n.42, p.8312-8319, aug, 2011.

LEORA SOFTWARE. POLO-PC: a user's guide to probit analysis or logit analysis. Berkeley, CA: Leora Software, 1987, 58p.

LIMA, R.K. et al. Caracterização química do óleo essencial de folhas de goiabeira (Psidium guajava L.) e seus efeitos no comportamento da lagarta-docartucho do milho Spodoptera frugiperda (J. E. Smith, 1797) (Lepidoptera: Noctuidae). Ciência e

Agrotecnologia, Lavras, v.33, Edição Especial, p.17771781, 2009.

LIMA, R.K. et al. Chemical composition and fumigant effect of essentialoil of Lippia sidoides Cham. and monoterpenes against Tenebrio molitor (L.) (Coleoptera: Tenebrionidae). Ciência e Agrotecnologia, Lavras, v.35, n.4, p.664-671, jul/aug, 2011.

LUBECK, A.J.; SUTTON, D.L. Kovats retention indices of selected hydrocarbons through $\mathrm{C}_{10}$ on bonded phase fused silica capillaries. Journal of High Resolution Chromatography \& Chromatography Communications, Weinhein, v.6, n.6, p.328-332, jun,1983.

LUOGEN, C. et al. Genetic analysis of resistance to dimehypo in diamondback moth, Plutella xylostella L. (Lepid., Plutellidae), by representational difference analysis. Journal of Pest Science, Berlin, v.78, n.3, p.117122, jun, 2005. 
MARTINS, R.M. Estudio in vitro de la acción acaricida del aceite esencial de la gramínea Citronela de Java (Cymbopogon winterianus Jowitt) en la garrapata Boophilus microplus. Revista Brasileira de Plantas Medicinais, Botucatu, v.8, n.2, p.71-78, apr./june, 2006.

MENDONÇA, F.A.C. et al. Activities of some Brazilian plants against larvae of the mosquito Aedes aegypti. Fitoterapia, Milano, v.76, n.7-8, p.629-636, oct, 2005.

MORAIS, L.A.S. Influência dos fatores abióticos na composição química dos óleos essenciais. Horticultura Brasileira, Brasília, v.27, Ed. esp., p.4050-4063, 2009.

MOREIRA, H.J. da C.; ARAGÃO, F.D. Manual de pragas da soja. Campinas: FMC, 2009, 144p.

MOREIRA, A.N. et al. Variação sazonal de espécies de tripes em videira de acordo com sistemas de manejo e fases fenológicas. Pesquisa Agropecuária Brasileira, Brasília, v.47, n.3, p.328-335, mar, 2012.

OLIVO, C.J. et al. Óleo de citronela no controle do carrapato de bovinos. Ciência Rural, Santa Maria, v.38, n.2, p.406-410, mar./apr, 2008.

PINENT, S.M.J.; CARVALHO, G.S. Biologia de Frankliniella schultzei (Trybom) (Thysanoptera: Thripidae) em tomateiro. Anais da Sociedade Entomológica do Brasil, Londrina, v.27, n.4, p.519-524, dec, 1998.

QUINTANS-JÚNIOR, L.J. et al. Phythochemical screening and anticonvulsant activity of Cymbopogon winterianus Jowitt (Poaceae) leaf essential oil in rodents. Phytomedicine, Stuttgart, v.15, n.8, p.619-624, aug, 2008.

RILEY, D.G. et al. Thrips vectors of tospoviruses. Journal of Integrated Pest Management, Johnston, v.1, n.2, p.1-10, aug, 2011.

RONDELLI, V.M. et al. Associação do óleo de mamona com Beauveria bassiana no controle da traça-dascrucíferas. Pesquisa Agropecuária Brasileira, Brasília, v.46, n.2, p.212-214, feb, 2011.

RONDELLI, V.M. et al. Composição química e avaliação do potencial inseticida do óleo essencial de Chenopodium ambrosioides no controle de Frankliniella schultzei. Enciclopédia Biosfera, Goiânia, v.8, n.15, p.2450-2458, nov, 2012.

SOARES, C.G. et al. Efeito de óleos e extratos aquosos de Azadirachta indica A. Juss e Cymbopogon winterianus Jowitt sobre Nasutitermes corniger Motschuls (Isoptera: Termitidae). Revista Ciências Agrárias, Belém, v.50, n.2, p.107-116, jul/dec, 2008.

VIEGAS, J.C. Terpenos com atividade inseticida: uma alternativa para o controle químico de insetos. Química Nova, São Paulo, v.26, n.3, p.390-400, may./june, 2003.

WASIKY, R.; AKISUE, G. Um novo aparelho aperfeiçoado para extração de óleos essenciais. Revista da Faculdade de Farmacia e Bioquimica da Universidade de São Paulo, São Paulo, v.7, n.2, p.399405, jul/dec, 1969. 